\title{
Tonal Adaptation Strategies in Èwùlù and Ùrhòbò Loanword Phonologies
}

Utulu, Don C. ${ }^{1}$, PhD, Ajiboye, Emuobonuvie ${ }^{2}$ M. and Ajede, Chika K. ${ }^{3}$

${ }^{1}$ Department of Languages and Linguistics, Faculty of Arts, Delta State University, Abraka, Delta State, Nigeria

${ }^{2}$ Department of Languages and Linguistics, Faculty of Arts, Delta State University, Abraka, Delta State, Nigeria

${ }^{3}$ Department of Linguistics and African Languages, Faculty of Arts, University of Ibadan, Oyo State, Nigeria

Corresponding Author: Utulu, Don C., PhD, E-mail: donutulu@gmail.com

\section{ARTICLE INFO}

Article History

Received: August 01, 2020

Accepted: September 15, 2020

Volume: 3

Issue: 9

DOI: $10.32996 /$ ijltt.2020.3.9.9

\section{KEYWORDS}

Èwùlù, Ùrhòbò, loanword, tonal adaptation, English stress

\section{ABSTRACT}

Studies on tonal adaptation strategies in English loanwords of the Nigerian languages $(\mathrm{NLs})$ : Yoruba $(\mathrm{Y})$, Hausa $(\mathrm{H})$, Bini $(\mathrm{B})$ and Emai $(\mathrm{E})$ commonly translate the prosodic structure of the loanwords into native prosodic configurations. Translation of pitch melody of borrowed words in the NLs tends to be determined by the position of English word stress. Comparative/typological studies that independently examine such tonal adaptation in Nigerian smaller languages are scanty. Consequently, this paper examines the pattern of word stress adaptation into tone in English loanwords in Èwùlù (Igboid) and Ùrhòbò (Edoid), with a view to revealing the Ėwùlù and Ùrhòbò tonal adaptation features common to $Y, H, B$ and $E$ but specific to Èwùlù and/or Ùrhòbò. The empirical observations of data are explained with Autosegmental Theory (Goldsmith, 1976), which formally expresses the relations that hold between the tone loans, tone bearing units and CV nodes operating at different tiers. Findings of this study show/confirm that the English citation pitch accent $\mathrm{H}^{*} \mathrm{~L} \%$ basically governs the domain of adaptation of $(\mathrm{H})$ igh tone and (L)ow in loans. Moreover, findings reveal that inserted vowels in CC-clusters in Èwùlù and Ùrhòbò loans are inherently toneless, acquiring their tones from adjacent tones. However, the study identifies two salient peculiar patterns: (1) Ùrhòbò assigns low tone on intervening $\mathrm{V}$ element in CC-cluster, a domain characteristically assigned $\mathrm{H}$ tone in Èwùlù, $Y, H, B$, and $E$. (2) Ùrhòbò regularly simplifies source $H^{*} L \%$ as $/ H$ / in adapted source $\mathrm{CVC}$, a context where Èwùlù and the aforementioned NLs rather adapt /H.L/ melody to realise vowel doubling. To this end, the current researchers recommend further comparative or typological studies on English loanwords in other NLs to further identify patterns of tone adaptation and resyllabification rules in loanwords similar to those of Urhobo in particular.

\section{Introduction}

A number of articles have emerged on the adaptation of stress with tone in English loanwords in Nigerian languages. The studies are particularly those carried out on two major Nigerian languages, e.g. Yoruba (Pulleyblank, 1986; Akinlabi, 1997; Ufomata, 1991; 2004; Kenstowicz, 2004, among others), Hausa (Kenstowicz, 2004). The tone loan data in the languages show systematic replacement of English stress with tone. For example, in Yoruba the words 'tomato' /ta 'ma:tav/and 'paper' /'peıpə/ are rendered as /tòmátò/ and /pépà/ respectively. In the Yoruba examples, as the studies demonstrate, major (strong) stress is adapted with high $(\mathrm{H})$ tone and non-major (weak) stress as low $(\mathrm{L})$ tone.

Similar tonal adaptation strategy has been shown to apply in English loans in Hausa. As Kenstowicz show, English words such as visa and parlour, among other items are adapted tonally as biizàa and fáalòo respectively, where the English main stressed syllable $v i-$, par- is adapted with $\mathrm{H}$ tone and the last (unstressed) syllables $\mathrm{L}$ tone. In the same vein, studies on loan phonologies of Edoid languages, e.g. Bini (Popoola, 1993) and Emai (Egbokhare, 1990) show pieces of tone marking that confirm similar adaptation of source strong and weak stress with $\mathrm{H}$ and $\mathrm{L}$ tones respectively.

K C AL-KINDI CENTER

$\mathbf{R}$ D FOR RESEARCH AND Your gateway to world-class research
Published by Al-KindiCenter for Research and Development. Copyright (c) the author(s). This is an open access article under CC BY license (https://creativecommons.org/licenses/by/4.0/) 
The researchers, (see particularly Ufomata, 2004) opine that the interaction of stress and tone in loans in Nigerian languages is attributed to the impact of years of contact between English and Nigerian languages. It has been suggested that the motivation of tone assignment rather than stress appears to be linked to a direct correspondence between the major stress of English and $\mathrm{H}$ tone in the borrowing language, on the one hand, or perhaps connected to correspondence based on fundamental frequency (FO), on the other hand. The latter assumption is hinged on the fact that stressed syllable of English is the site of $\mathrm{H}^{*}$ pitch accent in citation contours (Kenstowicz, 2004:136).

In the current study whose central goal is to describe and reveal common and peculiar tonal adaptation strategies in loans of smaller Nigerian languages in order to add to existing phonological literature on loan phonologies of Nigerian languages, it explores tone loans of two genetically different smaller Nigerian languages, specifically, Èwùlù (Igboid: Delta State; Utulu, 2015) and Ùrhòbò (Edoid, Delta State; Aziza \& Utulu, 2006). The data of this study is analysed using the multi-tiered model of the autosegmental theory (Goldsmith, 1976) which formally expresses the relations that hold between (1) the tone loans, (2) tone bearing units, and (3) CV nodes. Autosegmentally, according to Goldsmith, all three features operate at different levels of phonological representation.

\section{Literature Review}

The syllable structures of Èwùlù and Ùrhòbò, bearing in mind that tonal features under investigation in the current study cannot be isolated from the syllable which serves as domain for tone assignment. Basically, native Èwùlù and Ùrhòbò phonologies operate a two-tone system: the $\mathrm{H}$ tone and $\mathrm{L}$ tone plus downstep (!). Thus the two languages are West Benue Congo languages classified as registered tone languages (Utulu, 2015, Utulu, 2020; Aziza, 1997; 2010). An overview of the literature on the syllable and tone specification of Èwùlù and Ùrhòbò as well as the English syllable and word stress system is given in the next sub-sections.

\subsection{The Èwùlù Syllable Structure and Tone Specification}

Èwùlù operates basically three syllable types: the $V$ syllable, $N$ syllable and $C V$ syllable specified with some tone, $H, L$ or downstep. The $\mathrm{V}$ syllable type is predominant in pronominals. The $\mathrm{N}$ syllable followed by a $\mathrm{C}$ element is found in nominals where it ambisyllabic with the following $\mathrm{C}$. Thus both units, $\mathrm{N}+\mathrm{C}$ yielding / $\mathrm{n} . \mathrm{C} /$ sequence automatically generate a phonological concept called 'homorganicity'. The CV which is the optimal syllable in the lect is associated with simple verb roots. However, a large number of nominals have a combination of the N-CV and V-CV to form NCV and VCV nominals, respectively, as shown in the forms in (1) and (2) below.

Given the composition of the attested syllable structures in Èwùlù, its core syllable structure as posited in the foregoing is that which maximally contains a consonant followed by a vowel. Thus Ėwùlù syllable structure maximally contains only one consonant, a short vowel with no coda. In Èwùlù, the syllable is the Tone Bearing Unit (TBU) (Utulu, forthcoming), as examples in (1) demonstrate the syllable types and their tone specification:

(1)

$$
\begin{aligned}
& \text { V syllable and tone } \\
& \text { association }
\end{aligned}
$$
/ó/ 'he/she/it [+ATR]
/ó/ 'he/she/it [-ATR]
/í/ 'you' obj PRON [+ATR]
/i// 'you, obj PRON [-ATR]

$$
\begin{aligned}
& \mathrm{N} \text { syllable and tone } \\
& \text { association }
\end{aligned}
$$

$\begin{array}{lll}\text { /ḿ.bó/ } & \text { 'bullet' } & \text { /lé/ 'sell' } \\ \text { /ñ.dó/ } & \text { 'sorry' } & \text { /kú/ 'sow' } \\ \text { /ń.kú/ } & \text { 'wood' } & \text { /mé/ 'make' } \\ \text { /ńttà/ } & \text { 'soap' } & \text { /ná/ 'roast' }\end{array}$

As (1) illustrates, each syllable occupied by either the vowel or syllabic nasal is associated with some tone. In (2) a combination of $\mathrm{V}$ and $\mathrm{CV}$ syllable structure derives noun items in Èwùlù, with appropriate tones specified thus:

(2) V.CV syllable and tone association
/ź.kwà/ 'cloth'
/’́.nà/ 'trap'
/ú.mé/ 'strength'
/á.ló/ 'abomination'
/ó.dó/ 'mortar'

CV syllable and tone
association
/lé/ 'sell'
/kú/ 'sow'
/mé/ 'make'
/ná/ 'roast'


In (1) and (2), the $H$ and $L$ tones in Èwùlù may associate to any syllable in any positions in the word. However, it is interesting to note that, as will be shown in tonal adaptation of Èwùlù loanwords there is an absolute restriction on syllable positions where the $\mathrm{H}$ tone as opposed to the $\mathrm{L}$ tone can be specified. Below the syllable structure of Ùrhòbò is discussed.

\subsection{The Syllable Structure of Ùrhòbò and Tone Specification}

Ùrhòbò has three types of syllable structures: the V, CV and CCV (Aziza, 1997; 2010). According to Aziza (2010), the V is a representative of a word or a prefix in nouns, adjectives and demonstratives, while the $\mathrm{CV}$ is the predominant syllable structure in the language. The $V$ element can be found in word initial, medial and final positions. Moreover, the CCV which consists of two successive consonants followed by a vowel is phonotactically restricted. Aziza opines that the first consonant is obligatorily a labial/labio-dental or velar while the second consonant is obligatorily an alveolar tap / $/$, yielding a phonotactic string / $\mathrm{CrV} /$. Accordingly, the syllable borne by a vowel in Ùrhòbò is the TBU, as the following examples in (3) illustrate:

(3)

$$
\begin{aligned}
& \text { V syllable and tone } \\
& \text { association } \\
& \text { lé/ 'yes' } \\
& \text { ló/ 'he, she, it' } \\
& \text { ló/ 'he, she, it' }
\end{aligned}
$$

CV syllable and tone
association
CCV syllable and tone association

$\begin{array}{ll}\text { /sá/ } & \text { 'shoot, vb' } \\ \text { /gbé/ } & \text { 'dance, vb' } \\ \text { /yá-ré/ } & \text { 'divide' } \\ \text { /ó-mó/ } & \text { 'child' }\end{array}$

/sá/ 'shoot, vb'

/yá-ré/ 'divide'

$\begin{array}{ll}\text { /bru/ } & \text { 'cut, vb' } \\ \text { /mre/ } & \text { 'see, vb' } \\ \text { /kri/ } & \text { 'be late' } \\ \text { /hra/ } & \text { 'scatter' }\end{array}$

Source: (Aziza, 2010:284-5)

As one of the examples in (3) shows (see particularly the last example, /j'-mó/ 'child', V may combine with CV to generate a VCV syllable structure, similar to what obtains in Èwùlù, illustrated in (2). More importantly, it will be observed that in (3), level tones associate to all vowels that make up the syllable in Ùrhòbò. According to Aziza, the distribution of the levels, $\mathrm{H}$ tone or $L$ tone is not restricted; they can be found in any syllable positions, unlike downstep which is confined to final syllables of words or grammatical constructions.

Given the brief description of the basic syllable types in Ùrhòbò, it follows therefore that Ùrhòbò, like Èwùlù has a simple, open syllable structure. Consequently, this syllable type in both languages rules out closed syllable. The difference however between the two languages is that Ùrhòbò lack syllabic nasals. This phonological fact thus voids the operation of the homorganic nasal assimilation rule its native phonology. In the next Section, the English syllable and word stress are briefly reviewed.

\subsection{The Syllable and Word Stress in English}

The English syllable is relatively a complex one when compared with Èwùlù and Ùrhòbò. Blevins (1995) gives a description of ten possible syllable structures in English, ranging from V, CV, CVC to CVCCC syllable structure. In most accounts, the English syllable may contain two or three syllable onsets /CC.../ or /CCC.../ and four syllable codas /...CCCC/. These clusters are impossible in Èwùlù and Ùrhòbò, as shown in the forms in (1) through (3). The various forms of syllable structure alterations in loan adaptations, as the examples in subsequent Sections would reveal are manifestations of syllable structure asymmetries that exist between English versus Èwùlù and Ùrhòbò.

The role that the syllable plays in stress assignment in English deserves some brief discussion here. This is because, as will be shown in Section 4 and subsequent Sections, it is the same phonological unit which plays significant role in tonal adaptation in the two Nigerian languages under investigation. Specifically, word stress assignment in English is sensitive to syllable structure. Researchers (e.g. Chomsky and Halle, 1968; Giegerich, 1985; Kager, 1995, among others) have shown that word stress assignment in English is a complex one and is therefore not completely straightforward, though a number of rules have been formulated to capture generalisation of stress assignment in the language.

To begin with, a number of scholars working on the English stress system from a linear and non-linear perspectives (e.g. Chomsky and Halle, 1968; Liberman, 1975; Liberman and Prince, 1977; Kager, 1995, among many others) have shown that stress placement in English nouns (the lexical category that forms the bulk of corpus resource of most loanwords in second language pronunciation) tends to be determined by penultimate syllable. This is suggested by the underlined syllables in the

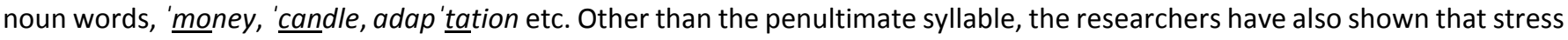
may target antepenultimate syllable, e.g. 'culpable, for'midable, a'pology etc. However, the researchers admit that other 
factors, such as affixation and weight profile of the syllable (light or heavy) and weight-by-position have strong influence on word stress assignment in English.

Basically, stress has been linked with prominence, in which the loudest syllable among several syllables within a word is said to be stressed. According to Kager (1995), stressed syllables are prominent syllables because, apart from being longer in duration, as well as of higher intensity, they are potentially capable of bearing pitch movements with strong perceptual load. Thus it has been suggested that stress and high tone have close affinity in terms of prominence and neutral intonational/melodic pattern (Pierrehumbert, 1980; Goldsmith, 1981; 1999; Hayes, 1995, Yip, 2002). For instance, in native English citation pronunciation, words such as computer, attention, agenda, if said as a statement, have the tonal melody LH*L\%, where the $\mathrm{H}^{*}$ associates to the stressed penultimate syllables: $p u$, tten and gen respectively. Given these prosodic facts, of relevance is the tendency for the $\mathrm{H}^{*} \mathrm{~L} \%$ tone melody attracted to stressed syllable and unstressed syllable respectively to a fruitful description of tone loans in Èwùlù and Ùrhòbò in this current work.

\section{Methodology}

The data used for this study were culled from existing data (Aziza \& Utulu, 2006; Utulu, 2019). Additional data were collected from five Èwùlù and three Ùrhòbò native speakers with no formal education. Pronunciations of the five Participants were recorded using Zoom H2 Handy Recorder. Subsequently, the speech samples were analysed perceptually for analysis by the researchers.

\section{Results and Discussion}

This Section is devoted results and discussion on stress adaptation/translation into tone in Èwùlù and Ùrhòbò loanwords. It largely explores exiting loan data (Aziza and Utulu, 2006; Utulu, 2009; 2019) of varying syllable structures.

\subsection{Adaptation of English Head/Stressed and Non-head/Unstressed Syllables in Èwùlù and Ùrhòbò}

As earlier works demonstrate in other Nigerian language other than Èwùlù and Ùrhòbò, the current data show that citation words borrowed from English into Èwùlù and Ùrhòbò are characteristically adapted to English neutral melody $\mathrm{H}^{*} \mathrm{~L} \%$., where $\mathrm{H}^{*}$ is associated with stressed (or head) syllable and translated to $\mathrm{H}$ tone in Èwùlù and Ùrhòbò. In the forms in (4) for example, Èwùlù adapts the English $\mathrm{H}^{*}$ associated with stress (head) syllable to $\mathrm{H}$ tone; and $\mathrm{L} \%$ associated with unstressed (or non-head) syllable is adapted to $L$ tone, thus:

(4) English stress on penultimate syllable and Èwùlù adaptation

English
a. /'do.lə/
$H^{*} L \%$
$\rightarrow$
/dó.là/
'dollar'
b. /'bn.tə/
$H^{*} L \%$
$\rightarrow$
/bó.tà/
'butter'
c. /' kb.lə /
$H^{*} L \%$
$\rightarrow$
/kj́.lò
'colour'
d. /məl.'tı.nə/
$\mathrm{LH}^{*} \mathrm{~L} \%$
$\rightarrow$
/mò.tí.nà/
'Maltina'
e. /ri. 'dzaı.nə/
$\mathrm{LH}^{*} \mathrm{~L} \%$
$\rightarrow$
/rè.dzí.nà/
'Regina'
f. /tə.'jəø.tə/
$\mathrm{LH}^{*} \mathrm{~L} \%$
$\rightarrow$
/tò.jó.tà/
'Toyota'
g. /mə.'ski:təひ/
$\mathrm{LH}^{*} \mathrm{~L} \%$
$\rightarrow$
/mò.sì.kí.tò/
'mosquito'
h. /pə'teı.tə๘/
$\mathrm{LH}^{*} \mathrm{~L} \%$
$\rightarrow$
/pò.té.tò/
'potato'
i. /tə'ma:.təఠ/
$\mathrm{LH}^{*} \mathrm{~L} \%$
/tò.má.tò/
'tomato'

In the Ùrhòbò case, the interesting adaptation strategy in Èwùlù as in (4) is replicated in (5) as follows: 
(5) English stress on penultimate syllable and Ùrhòbò adaptation

English English Citation melody Ùrhòbò Gloss
a. /'dp.lə/
$H^{*} L \%$
$\rightarrow$ /ì.dó.là/
'dollar'
b. /'bn.tə/
$H^{*} L \%$
$\rightarrow$ /i.bó.tà/
'butter'
c. /' kb.lə /
$H^{*} L \%$
$\rightarrow$ /i.kó.lò
'colour'
d. /məl.'tı.nə/
$\mathrm{LH}$ * L\%
$\rightarrow$ /ì.mj̀.tí.nà/
$\rightarrow$ /ìrè.zí.nà/
$\rightarrow$ /i.tò.jó.tà/
LH*L\%
$\rightarrow$ /ì.mò.sì.kí.tò/
$\rightarrow$ /ì.pò.té.tò/
$\mathrm{LH} * \mathrm{~L} \%$
$\rightarrow$ /i.tò.má.tò/
'Maltina'
'Regina'
'Toyota'
g. /mə.'ski:tə兀/
$L H^{*} L \%$
'mosquito'
'potato'
i. /tə'ma:.təఠ/

Autosegmentally, as in (6), the Èwùlù and Ùrhòbò tonal adaptation enables the formalisation of the symmetrical stress-tone relations that hold between, first, source (English) penultimate stressed syllable versus $\mathrm{H}$ tone and, second, unstressed syllable versus $L$ tone thus:

(6) English
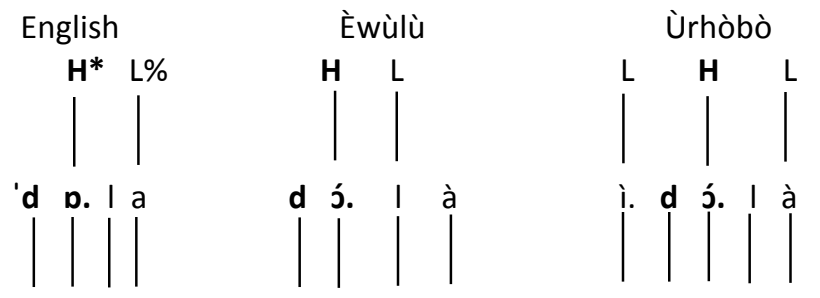

tonal tier

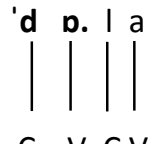

C V. C V

V. C V. C V

CV-tier

In (6) association lines capture the mode of adaptation of (and the link between) source neutral $\mathrm{H}^{*}$ intonation to $\mathrm{H}$ tone and source neutral $L \%$ to $L$ tone at the tonal tier. It is interesting to note that the English falling neutral intonation/F0 unequivocally navigates tone assignment on the adapted vocabulary in both Èwùlù and Ùrhòbò loans.

Furthermore, the antepenultimate stressed syllable in (7) and (8) helps to reinforce the fact that $H$ and $L$ tones are navigated by the position of stress and non-stress in the source vocabulary in the recipient languages thus:

English stress on antepenultimate syllable and Èwùlù tonal adaptation

\section{English}
a. /'mı.rə.kl/
b. /'kæ.mə.rə/
c. /'Iı.bə.ti/
d. /'se.nə.tə/
e. /'kæ.nə.də/
f. /'mæ.nı.dzə/
g. /'bæ.tə.lə/

English Citation melody

$\begin{array}{ll}\mathrm{H}^{*} \mathrm{ML} \% & \rightarrow \\ \mathrm{H}^{*} \mathrm{ML} \% & \rightarrow \\ \mathrm{H}^{*} \mathrm{ML} \% & \rightarrow \\ \mathrm{H}^{*} \mathrm{ML} \% & \rightarrow \\ \mathrm{H}^{*} \mathrm{ML} \% & \rightarrow \\ \mathrm{H}^{*} \mathrm{ML} \% & \rightarrow \\ \mathrm{H}^{*} \mathrm{ML} \% & \rightarrow\end{array}$

Èwùlù

/mí.rā.kù/

/ká.mē.rà/

/lí.bā.tì/

/sć.nē.tò/

/ká.nā.dà/

/má.nī.dzà/

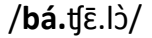

Gloss

'miracle'

'camera'

'liberty'

'senator'

'Canada'

'manager'

'bachelor'

A similar tonal adaptation strategy holds in both languages as (7) in comparison with (8) shows thus:

(8) English stress on antepenultimate syllable and Ürhòbò tonal adaptation

$$
\text { English English Citation melody Ùrhòbò Gloss }
$$
a. /'mı.rə.kl/
$H^{*} M L \%$
$\rightarrow \quad$ /ì.mí.rá.kò/
'miracle' 


\begin{tabular}{|c|c|c|c|c|}
\hline b. /'kæ.mə.rə/ & $H^{*} M$ L\% & $\rightarrow$ & /ì.ká.mé.rà/ & 'camera' \\
\hline c. /'lı.bə.ti/ & $H^{*} M$ L\% & $\rightarrow$ & /ì.lí.bá.tì/ & ‘liberty’ \\
\hline /'se.nə.tə/ & $H^{*} M$ L\% & $\rightarrow$ & /ì.sć.né.tò/ & 'senator' \\
\hline /'kæ.nə.də/ & $H^{*} M$ L\% & $\rightarrow$ & /ì.ká.ná.dà/ & 'Canada' \\
\hline /'mæ.nı.dzə/ & $H^{*} M$ L\% & $\rightarrow$ & /ì.má.né.zà/ & 'manager' \\
\hline g. /'bæ.†ə.lə/ & $H^{*} \mathrm{M} L \%$ & $\rightarrow$ & /ì.bá.fć.lj̀/ & 'bachelor' \\
\hline
\end{tabular}

The difference, however, is the Ùrhòbò innovation of low-toned initial (prothetic) vowels, Èwùlù $M$ tone and Ùrhòbò $H$ tone contrast assigned on the penultimate syllable, culminating ' $\mathrm{H}$ spread' in the latter language. By and large, Èwùlù tonal adaptation strategy is similar to English while that of Ùrhòbò is markedly different from the donor language. The graphic representation in (9) clearly demonstrates the similarity and difference in tonal adaption in both languages as follows:

(9)

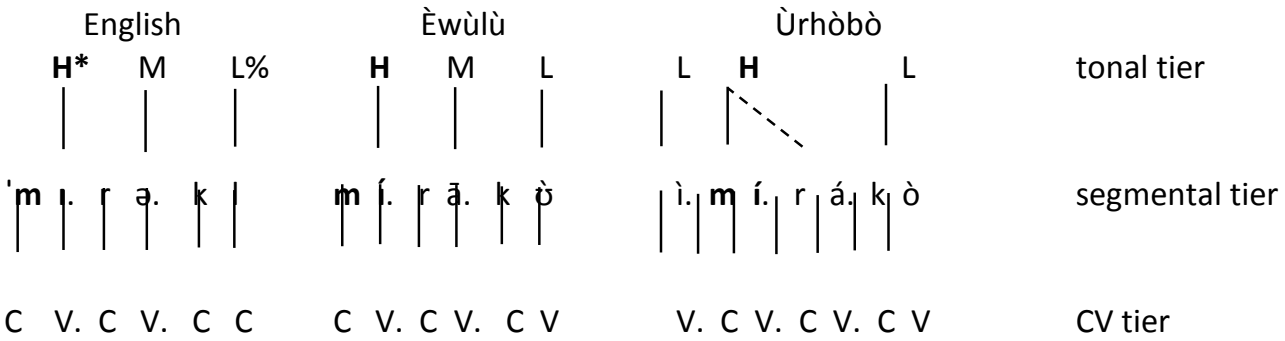

In (9), relations in tonal adaptation in Èwùlù and Ùrhòbò are transparently and insightfully brought to the fore. The Ùrhòbò $H$ tone spread, a form of ' $\mathrm{H}$ tone progressive assimilation' can be seen captured by broken association line, a pitch melody demotivated in English and Èwùlù.

\subsection{Tonal Adaptation on Epenthetic Vowels in Èwùlù and Ùrhòbò Loan words}

This section discusses and examines tonal adaptations on epenthetic (prothetic and anaptyctic) vowels in Èwùlù and Ùrhòbò loanwords. The adaptation strategy may apply in three positions: (1) loan initial. (2) medial, and (3) final positions, as demonstrated in the following subsections.

\subsubsection{Tonal Adaptation on Initial/Prothetic Vowel in Ùrhòbò Loanwords}

As mentioned earlier, Ùrhòbò employs prothetic vowel in loans. The vowel quality is consistently /i/, as shown in (5) and (8). This inserted vowel is introduced in that position because native Ùrhòbò noun vocabulary characteristically begins with vowel. Thus English noun loans with an initial consonant are subjected to the process that introduces a low-toned vowel/i/ in loanword initial position. In contrast, Èwùlù, as demonstrated in (4) and (7) does not employ this process. This is so because native noun words do and can begin with a consonant, evidenced by native forms such as, Chukwu 'God', nwa 'child' etc.

The L-toned inserted vowel in English loans in Ùrhòbò is governed by a restriction that sanctions L tone on unstressed syllable. Since inserted vowels are not head syllables, $\mathrm{L}$ tone rather than $\mathrm{H}$ tone is by rule assigned (Utulu, 2019).

\subsubsection{Tonal Adaptation on Vowels in CC-Cluster in Èwùlù and Ùrhòbò Loanwords}

Like in loan initial position, vowel is readily inserted in between two consecutive C elements otherwise known as CC-cluster. According to Aziza and Utulu (2006) and Utulu (2019), the inserted vowel also known as 'anaptyctic vowel' is employed to simplify the source complex syllable and consequently make it align with the optimal CV syllable structure of the two borrowing languages. The 'extra' vowel as Ufomata (2004) calls it automatically surface with some tone. Illustrations of the inserted vowel (in bold face print) in Èwùlù in (10) and that of Ùrhòbò in (11) are presented as follows:

(10) Tonal Adaptation in CC-cluster in Èwùlù loanwords

English English Citation melody Èwùlù Gloss

$\begin{array}{llll}\text { a. /'sket/ } & \mathrm{H}^{*} \mathrm{~L} \% & \text { /sí.ké.č.tì/ } & \text { 'skirt' } \\ \text { b. /'glæs/ } & \mathrm{H}^{*} \mathrm{~L} \% & \text { /gí.lá.àsi/ } & \text { 'glass' } \\ \text { c. /'traðzə/ } & \mathrm{H}^{*} \mathrm{~L} \% & \text { /tú.lá.zà/ } & \text { 'trouser' }\end{array}$



d. /'skol/
$\mathrm{H}^{*} \mathrm{~L} \%$
/sú.kú.ù.lù/
'school'
e. /'treen/
$\mathrm{H}^{*} \mathrm{~L} \%$
/tí.ré.è.nì/
'train'
f. /a'bro:d/
L. $H^{*} L \%$
/à.bú.ró.j̀.dù/
'abroad'

As (10) indicates, all inserted vowels in between source CC-clusters acquire $H$ tone. In (11) Ùrhòbò assigns some tone as well; but in its peculiar case, $L$ tone is rather inserted, thus:

(11) Tonal Adaptation in CC-cluster in Ùrhòbò loanwords

\begin{tabular}{|c|c|c|c|}
\hline English & English Citation melody & Ùrhòbò & Gloss \\
\hline a. /'sket/ & $H^{*} L \%$ & /î.sì.ké.tì/ & 'skirt' \\
\hline /'glæs/ & $H^{*} \mathrm{~L} \%$ & / ì.gì.lá.sì/ & 'glass' \\
\hline /'trauzə/ & $H^{*} \mathrm{~L} \%$ & / ì.tù.rá.zà/ & 'trouser' \\
\hline /'skol/ & $H^{*} L \%$ & / ì.sù.kú.lù/ & 'school' \\
\hline e. /'treın/ & $H^{*} L \%$ & / ì.tì.ré.nì/ & 'train' \\
\hline f. /ə' bro:d/ & L. $H^{*} L \%$ & /à.bù.ró.dù/ & 'abroad' \\
\hline
\end{tabular}

As demonstrated in Utulu (2019), see also Ufomata (2004) on Yoruba, the Èwùlù and Ùrhòbò extra vowels in this domain are toneless. Each of the borrowing language assigns its peculiar tone melody based on that of the adjacent syllable. Accordingly, the source of Èwùlù $\mathrm{H}$ tone is from the initial syllable corresponding to English stress syllable while the source of Ùrhòbò $L$ tone is from the prothetic vowel. Interestingly, however, regardless of the source of tone of the inserted vowels in the two languages, it is evident that these extra vowels are toneless, as suggested in the literature. A case in point is Yoruba extra vowels in loanwords (Ufomata, 2004). The two respective tonal adaptation patterns are captured autosegmentally in (12) and (13), citing the form in (10a) and (11a) /' sket/ 'skirt' as follows:

(12)

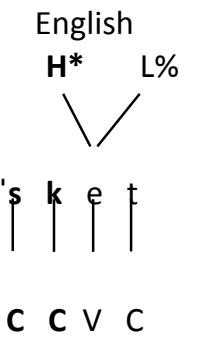

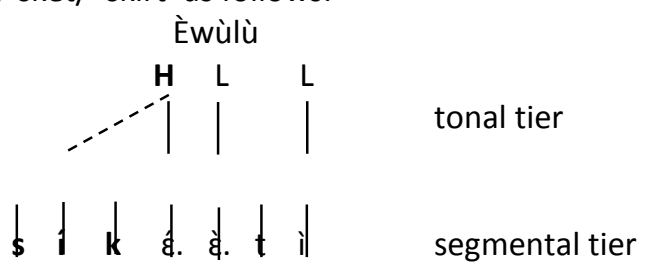

C V. C V. V. C V CV tier

As (12) indicates, anaptyctic vowel /í/ $\mathrm{H}$ tone, the direct correspondence of English $\mathrm{H}^{*}$ spreads its melody (see broken association line) to the left, a curious type of regressive $\mathrm{H}$ tone spread. In Ùrhòbò however the direction of the tone spread, $\mathrm{L}$ tone spread to be precise, (see broken association line) is different, as (13) demonstrates:

(13)

English Ùrhòbò

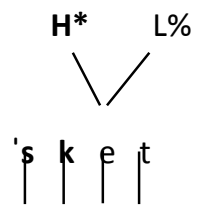

C C V C

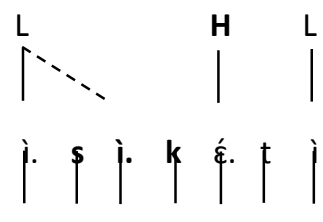

V. C V. C V. C V tonal tier

segmental tier

CV tier

In (13), anaptyctic vowel /i/ L tone acquire its tone from the prothetic low-tone vowel /i/ in a left-to-right direction, yielding a form of progressive $L$ tone spread. 


\subsubsection{Tonal Adaptation in Final Anaptyctic Vowels in Èwùlù and Ùrhòbò Loanwords}

The tone loan of final anaptyctic vowels is quite predictable given the fact that it is regularly $L$ tone, like that of any other extra vowels. This tonal adaptation pattern has been reported in Hausa and Yoruba loanwords (see Pulleyblank, 1986; Akinlabi, 1993; Kenstowicz, 2004; Ufomata, 1991, 2004, among others); Igbo (Utulu, 2019) and Bini and Emai (Popoola, 1993; Egbokhare, 1990). All the examples presented in previous Sections crucially demonstrate this salient tonal pattern and hence need not be independently discussed or re-analysed here.

\subsubsection{Tonal Adaptation in English CVC in Èwùlù and Ùrhòbò Loanwords}

Tonal adaptation in English loans with CVC syllable structure, see (10a, b, d-f) and (12) examples presents an interesting pattern. This is so because of the peculiar way in which Èwùlù and Ùrhòbò together with other languages of the West Benue Congo language family resyllabify the CVC syllable structure. Phonologists working on resyllabification pattern of English CVC in loans (some of whom have been mentioned in Section 4.2.3) show that source CVC is normally modified as /(V).CV.V.CV/. In particular, the typical rendering of the English word, for example, 'bed' /bed/in Yoruba is/bć.è.di/, Igbo /bć.c̀.di/ (or, bé.è.di),

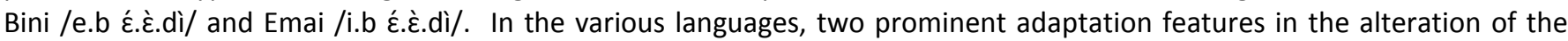
prosody of CVC loans, following Utulu's (2019) analysis are:

(1) insertion or duplication of a copy of the source singleton vowel /e/, yielding /źż/, in what is technically referred to as vowel doubling (VD) in the literature.

(2) assignment of H.L tone melody, a direct correspondence of the English citation FO contour H*L\%.

Thus the prosodic patterns of CVC loans are, as in Èwùlù (14) and in Ùrhòbò (15):

$$
\text { Èwùlù Gloss }
$$

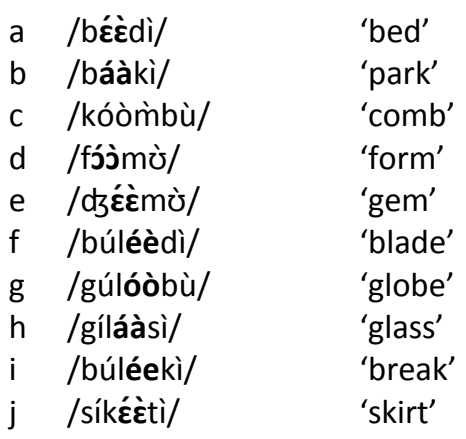

Adapted from Utulu (2019:35)

In (14) the entire English V-elements are doubled in Èwùlù loans. The Ùrhòbò pattern presented in (15) indicates that English V-elements remain single:

\begin{tabular}{|c|c|c|c|}
\hline & English & Ùrhòbò & Gloss \\
\hline a & /bed/ & /ibźdi// & 'bed' \\
\hline b & /n3:s & /înósì/ & 'nurse' \\
\hline c & /bæg/ & /îbágì/ & ‘bag' \\
\hline$d$ & /fo:m/ & /îfómù/ & 'form' \\
\hline e & /kıp/ & /îkópù/ & ‘cup' \\
\hline$f$ & / /3:t/ & /îfétì/ & 'skirt' \\
\hline g & /kJ:t/ & /ikótù/ & 'court' \\
\hline h & /kəəm/ & /ikómù/ & 'comb' \\
\hline i & /sk3:t/ & /isikéti// & 'skirt' \\
\hline j & /glæs/ & /ìginásì/ & 'glass' \\
\hline
\end{tabular}

Adapted from (Utulu, p. 37) 
Given the patterns of adaptation of the CVC syllable structure, it is obvious that the strategy Èwùlù adopts is markedly different from that of Ùrhòbò, include unattested intruding L-tone prothetic vowel. The marked difference in the mode of tone transfer in both languages, as Utulu suggests, is hinged on constraint on the peculiar tonal grammar of the borrowing languages, which applies on a language specific terms. While Èwùlù (see Utulu, 2020) allows H-L tone sequence ambisyllabically in native tonal/grammatical constructions, giving rise to vowel doubling in (14), Ùrhòbò (see Aziza, 2007) disallows native ambisyllabic $\mathrm{H}-\mathrm{L}$ tone sequence in the same domain, a situation that blocks VD as demonstrated in (15).

Consequently, in Ùrhòbò, only the $\mathrm{H}$ is retained while the $\mathrm{L}$ is elided. As it were, the two native tonal contrasts apparently impact strongly upon the prosodic structure of English loanwords. It is pertinent to note that Ùrhòbò treatment of English CVC loans is not only different from Ewulu, as it is quite different from that recorded in languages such as Yoruba, Igbo, Bini and Emai all of which are the same with what obtains in CVC loans in Èwùlù.

\subsection{Common Typology of Tonal Adaptation Strategies in the Nigerian Context}

The following are the tone loan adaptation strategies in Èwùlù and Ùrhòbò loan phonologies, which are also attested in Yoruba, Igbo, Hausa, Edo and Emai loanword phonologies:

a. The first strategy shows that stressed syllable (head syllable) in English source vocabulary is adapted with high (H) tone.

b. The second strategy shows that (final) unstressed syllable (non-head syllable) is adapted with low (L) tone.

c. V-elements of CC-clusters are toneless; they take their tone from the tone of adjacent syllable.

d. Loanword prothetic vowels in Ùrhòbò attract $L$ tone, a tonal adaptation strategy quite common loan phonologies of Edoid group of languages to which Ùrhòbò belongs.

e.

\subsection{Language-Specific Tonal Adaptation Strategies in the Èwùlù and Ùrhòbò Context}

a. The $L$ tone associated to the second component of VD in CVC is not attested in Ùrhòbò. The absence of $L$ tone thus rules out VD in CVC loans.

b. Loanword prothetic vowels are absent in Èwùlù. This resyllabification rule is equally absent in Yoruba, Igbo and Hausa loan phonologies (see Pulleyblank, 1986; Kenstowicz, 2004). Thus tone assignment in this position is ruled out.

C. The V elements of CC-cluster in Èwùlù and Ùrhòbò, though are toneless, the quality of tone differs in both languages. Èwùlù assigns $\mathrm{H}$ tone copied from adjacent syllable in this domain while Ùrhòbò assigns $\mathrm{L}$ tone also copied from adjacent syllable.

\section{Conclusion}

This study has provided further insight into the phonological data of tone loans adaptation strategies in Nigerian languages (NLs). It has revealed areas of recurrent adaptation strategies as well as areas peculiar to loan phonologies of Èwùlù versus Ùrhòbò, and those of Ùrhòbò versus Igbo/Èwùlù, Yoruba, Hausa, Bini and Emai. To this end, the current researchers recommend further comparative or typological studies on English loanwords in other NLs to further identify patterns of tone adaptation and resyllabification rules in loanwords similar to those of Urhobo in particular.

\section{References}

[1] Akinlabi, A.M. (1993). Underspecification and the phonology of /r/. In Linguistic Inquiry 2, 139-60.

[2] Akinlabi, A.M. (1997). Patterns of tonal transfer I. $28^{\text {th }}$ Annual Conference on African Linguistics. Cornell University, Ithaca.

[3] Aziza, R.O. (1997). Ùrhòbò tone system. Unpublished Ph.D Thesis, University of Ibadan.

[4] Aziza, R.O. (2010). Ùrhòbò phonology. In Y. Ore (Ed.) Basic linguistics for Nigerian languages, 278-94.

[5] Aziza, R O. 2007. Phonological processes and their effect on lexical tones in Urhobo. In O-M, Ndimele (ed.) Nigerian languages, literatures, culture and reforms [a festschrift in honour of Ayo Bamgbose, 461-74.

[6] Aziza, R.O and Utulu D.C. (2006). Loanword phonology: English in Ùrhòbò and Yoruba'. In K.L. Hamrod (ed.) Journal of West African languages. West African Linguistic Society, 33 (2), 3-21.

[7] Blevins, J. (1995). The syllable in phonological theory. In Goldsmith, J.A. (Ed.). The handbook of phonological theory, 206-44.

[8] Chomsky, N and Halle, M. (1968). The sound pattern of English. New York. Haper and Row.

[9] Egbokhare, F.O. (1990) A phonology of Emai. PhD Thesis, University of Ibadan.

[10] Goldsmith, J. (1976). Autosegmental phonology. PhD dissertation, MIT [published 1979, New York: Garland].

[11] Goldsmith, J. (1981). English as a tone language. In D Goyvaerts (Ed.). Phonology in the 1980s, Ghent: Story Scientia, $287-308$.

[12] Goldsmith, J. (1999). An overview of autosegmental phonoloy (1976). In J.A. Goldsmith (Ed.). Phonological theory: The essential readings. Blackwell, 137-61. 
[13] Giegerich, H. (1985). Metrical phonology and phonological structure. Cambridge: Cambridge University Press.

[14] Hayes, B. (1995). Metrical stress theory: principles and case studies. Chicago: University of Chicago Press.

[15] Kager, R. (1995). The metrical theory of word stress. In J.A. Goldsmith (Ed.), The handbook of phonological theory, Blackwell, 367-402.

[16] Kenstowicz, M. (2004). Tone loans: the adaptation of English loanwords into Yoruba. J. Mugane et al (eds.). Selected proceedings of the 35th annual conference on African linguistics, 136-46.

[17] Liberman, M. (1975). The intonational system of English. Doctoral Dissertation, MIT.

[18] Liberman, M. and A. Prince, (1977). On stress and linguistic rhythm. Linguistic Inquiry, 8:249-336.

[19] Pierrehumbert, J. (1980). The phonology and phonetics of English intonation. Ph.D Dissertation. MIT.

[20] Popoola, R. (1993). Vowel insertion in Yoruba, Edo and Igbo. M.A Dissertation, University of Ibadan.

[21] Pulleyblank, D. (1986). Tone in lexical phonology. Reidel, Dordrecht.

[22] Ufomata, T. (1991). Englisization of Yoruba phonology. World Englishes 10: 33-51.

[23] Ufomata, T. (2004). Tone and stress in contact: the example of English loanwords in Yoruba. In K. Owolabi and Dasylva, A (Eds.), Forms and functions of English and indigenous languages in Nigeria [a Festschrift in Honour of Ayo Banjo], 577-92.

[24] Utulu, D.C. (2009). Syllable weight and vowel lengthening in Èwùlù loanword phonology. In papers in English and linguistics (PEL), Linguistics Association of Nigeria, Obafemi Awolowo University, Ile-Ife, 10, 70-81.

[25] Utulu, D.C. (2015). Èwùlù tone system: A preliminary investigation. University of Uyo Journal of Humanities, The Faculty of Arts, University of Uyo, Akwa Ibom, 19 (1), 106-25.

[26] Utulu, D.C. (2019). Vowel doubling in Ùrhòbò: The case of loanword. Journal of West African Languages, 46 (1), 32-46.

[27] Utulu, D.C. (2020). A description of some structures of (un)derived tones in Ewulu nouns. In European Journal of Literature, Language and Linguistics Studies, 4 (2), 36-51,

[28] Utulu, D.C. [forthcoming] Syllable constraints as triggers of repair strategies: Evidence from Èwùlù phonological processes, p. 1-18.

[29] Yip, M. (2002). Tone. Cambridge: Cambridge University Press. 